\title{
Collaborative meta-profile development to harmonise mechanical engineering education in Africa
}

\author{
Samuel M. Sackey, Venkata Ramayya Ancha, Moses P.M. Chinyama, \\ Charles Awono Onana, Raïdandi Danwe, Mohammad M. Megahed, \\ Béatrice Delpouve, Shadreck Chama, Nawaz Mahomed,
} Venant Kayibanda, Léonard Kabeya Mukeba Yakasham, and André Müller

\begin{abstract}
This paper describes the contribution of the Tuning Methodology toward harmonisation of undergraduate mechanical engineering programmes in Africa. This methodology is an interactive process in which academics develop high quality curricula and learning standards for students through the identification of generic and subject specific competences in consultation with employers, students, graduates, peers and other stakeholders involved in Mechanical Engineering higher education. The current Tuning process involves academics in 11 universities drawn from across Africa. The aim is to collaboratively contribute to revitalizing and reforming Mechanical Engineering higher education in Africa to make it more responsive to Africa's developmental needs. The results so far show that such a project is not only highly feasible but also holds promise for establishing compatible academic structures and reference standards across Africa, which would facilitate student and staff mobility as well as enhance cooperation not only among African academic institutions, but also between African institutions and those in the rest of the world. Eighteen generic competences and nineteen mechanical engineering-specific competences are developed, analysed and synergised to form a meta-profile that will inform the next phase of the project, which is the actual curriculum development. This activity is part of "Tuning Africa" project, which is funded through European Union-African Union collaboration.
\end{abstract}

Keywords: Tuning methodology; mechanical engineering; higher education; competences; meta-profile development.

\section{Introduction}

The African Higher Education system is undergoing a tremendous transformation process. This includes a number of initiatives among which are the Nyerere Mobility Scheme, the African Higher Education Harmonisation and Quality Assurance programme, and the Pan African University. However, at the institutional level, reforms are underway, even as socio-economic development issues emerge as a fundamental policy driver among many African countries. Traditionally, African countries have failed to exploit 
opportunities for increased intra-African trade, although organizations such as Economic Community of West African States (ECOWAS), South African Development Community (SADC) and others exist to strengthen regional cooperation in development. It is envisaged that key future development projects such as expanding transport networks and shared infrastructure will require cooperation amongst engineers from different African countries.

At the present time rapid developments from the international scene in the area of curriculum development are impacting African higher education in several ways many engineering higher education curriculum development studies reported in the literature ${ }^{1}$ have focussed on the globalisation dimension of engineering education. Others studies ${ }^{2}$ have discussed the achievability of standards set by accreditation bodies, observing that unrealistic requirements could raise legitimate questions as to whether these skills can be effectively imparted and evaluated. Still others ${ }^{3}$ have discussed various relevant issues including teaching, learning, and curriculum design methodologies. A few more $^{4}$ studies researchers have analysed the impact of engineering curriculum reform on economic growth and sustainability while a handful others ${ }^{5}$ have focused mainly on industry's perspective and its demands on the engineering graduate. Some researchers have restricted themselves to tracking the progress of specific engineering disciplines in specific countries or regions of the world such as Industrial Engineering in Peru, ${ }^{6}$ and its relationship to current major trends in Europe and North America. In all these works, it is commonly recognized that the formation of engineers through education requires not only the acquisition and strengthening of technical knowledge,

${ }^{1}$ Jackson, H., Tarhini, K., Zapalska, A., and Zelmanowitz, S., "Strategies to Infuse Global Perspectives and Industrial Collaboration in Engineering Education" (40 ${ }^{\text {th }}$ ASEE/IEEE Frontiers in Education Conference, Washington, DC, October, 2010).

2 "The ABET "Professional Skills" - Can They Be Taught? Can They Be Assessed?" Journal of Engineering Education 94, no. 1 (2005): 41-56.

${ }^{3}$ Strobel, J., Wang, J., Weber, N.R., Dyehouse, M., "The role of authencity in designbased learning environments: The case of engineering education," Computers \& Education 64 (May 2013):143-152.

${ }^{4}$ Kumar, V., Karl R. Haapala, Julio L. Rivera, Margot J. Hutchins, William J. Endres, John K. Gershenson, Donna J. Michalek, John W. Sutherland, "Infusing sustainability principles into manufacturing/mechanical engineering curricula," Journal of Manufacturing Systems 24, no. 3 (2005): 215-225.

5 Markes, I., "A review of literature on employability skills needs in engineering," European Journal of Engineering Education 31, no. 6 (2006): 637-650.

${ }^{6}$ Martín P., Ignacio de los R., Dante G., Higher Education in Industrial Engineering in Peru: Towards a New Model Based on Skills. Procedia - Social and Behavioral Sciences 46, no. 2 (2012): 1570-1580 (paper originally presented at the 4th World Conference on Educational Sciences, WCES-2012, Barcelona, Spain, February 2-5, 2012). 
but also the development of the competences that are required by both employers and other recipients of the benefits of engineering, i.e. society.

In Africa, recent intra-African technology development initiatives such as Satellite Technology programme, the Square Kilometre Array (SKA) Programme, the African Laser Centre, regional hydropower building programmes etc., have brought to the fore the need for harmonisation of engineering programmes across Africa, and the development of curricula that address the specific technological needs of the continent. ${ }^{7}$

The requirements of technology transfer, adaptation and assimilation further underline the need for harmonisation of engineering curricula across Africa. Such harmonisation will enhance intra-African human resource mobility at various levels, namely: high-level research in areas of specialization which necessitate judicious use of scarce and expensive resources, postgraduate programmes in specialist areas, and joint engineering programmes based on intra-African meta-profiles.

\section{Tuning Methodology}

\section{The place of Tuning}

One transformation initiative which links institutional, national, regional, continental and international endeavours is the African Higher Education Harmonisation and Tuning Project (Tuning Africa), which is part of an AUEU strategic partnership initiative. ${ }^{8}$ The importance of the Tuning methodology as an instrument for systematic Higher Education reform and quality enhancement has been highlighted in the literature. ${ }^{9}$ Specific success cases such as those relating to using the methodology to determine student workload and degree profiles in Latin America have also been discussed in the literature. ${ }^{10}$ The Tuning methodology itself is an interactive process in

7 Galal Abdel-Hamid Abdellah et. al., "Recent developments in Egyptian engineering education through competitive projects," 2008 (paper presented at the Third African Regional Conference on Engineering Education (ARCEE), courtesy the African Engineering Education Association (AEEA), Pretoria, South Africa, September 26- 27, 2006).

8 Tuning Africa Project, www.tuningafrica.org.

9 Karola Hahn and Dantew Teferra, "Tuning as instrument of systematic Higher Education reform and quality enhancement: the African experience," Tuning Journal for Higher Education, no. 1 (2013): 128.

${ }^{10}$ Francisco Alarcon, Pablo Beneitone, Roberto de Armas, Sergio Kieling, Leticia Sune, and Diana Veneros, "Student Workload and Degree Profiles: the experience of CLAR credit in Latin America," Tuning Journal for Higher Education, no. 1 (2013): 165. 
which academics develop high quality curricula and learning standards for students through the identification of generic and subject specific competencies in consultation with employers, students, graduates, peers and other stakeholders involved in higher education.

Mechanical engineering (ME) is one of five subject areas whose harmonisation is being piloted in Africa as part of the above initiative with representation from countries shown in Table 1.

Table 1

List of universities and countries participating in the ME Tuning project

\begin{tabular}{|l|l|}
\hline $\begin{array}{l}\text { 1) Cameroon - University de } \\
\text { Yaounde I (Coordinator) }\end{array}$ & $\begin{array}{l}\text { 2) France, University of Lille 1-Science } \\
\text { and Technology (European Facilitator) }\end{array}$ \\
\hline $\begin{array}{l}\text { 3) Democratic Republic of } \\
\text { Congo - Institut Supérieur de } \\
\text { Techniques Appliquées Kinshasa }\end{array}$ & 4) Egypt - Cairo University \\
\hline 5) Ethiopia - Jimma University & $\begin{array}{l}\text { 6) Ghana - Kwame Nkrumah } \\
\text { University of Science and Technology }\end{array}$ \\
\hline $\begin{array}{l}\text { 7) Malawi - University of } \\
\text { Malawi - the Polytechnic }\end{array}$ & $\begin{array}{l}\text { 8) Rwanda - Kigali Institute of } \\
\text { Science and Technology }\end{array}$ \\
\hline 9) Zambia - Copperbelt University & $\begin{array}{l}\text { 10) South Africa - Stellenbosch } \\
\text { University }\end{array}$ \\
\hline $\begin{array}{l}\text { 11) South Africa - Cape Peninsula } \\
\text { University of Technology }\end{array}$ & \\
\hline
\end{tabular}

The history of the Higher Education tuning started in the year 2000 in Europe following the Bologna process; it then moved on to Latin America, Russia, Georgia and other countries. Tuning holds the promise of establishing compatible academic structures, and reference standards across Africa, which could facilitate student and staff mobility, promote compatibility of degrees and qualifications as well as enhance cooperation, not only among African academic institutions, but also between African institutions and those in the rest of the world.

\section{Tuning mechanical engineering}

The objective of the first phase of "Tuning Africa" applied to Mechanical Engineering is to form what should be a typical "Mechanical Engineering" 
(ME) degree profile in Africa. This is termed here as the degree "Meta-Profile". The procedure followed in developing this meta-profile includes the definition of ME, development of a suitable professional profile of an ME graduate, and evolution of initial set of generic and subject-specific graduate competencies. Consultation processes with four stakeholder groups then followed. These are: academics, employers, students, and graduates. These stakeholders were asked to indicate the level of "importance" and the level of "achievement" of each generic and subject specific competence and in addition to rank all competencies in a descending order of importance. This ranking is made on a scale of 1 to 4 as follows: strong $=4 / 4$, moderate $=3 / 4$, weak $=2 / 4$, none $=1 / 4$. Finally, a reordering and classification of the competencies based on the consultation results, led to the development of a Mechanical Engineering meta-profile.

\section{Development of generic and ME-specific competencies}

Sessions of extensive discussions and deliberations among representatives of the participating African Universities focussed on developing two sets of competencies. The first set is to be common to graduates of all disciplines and hence is termed as "Generic Competencies". The second set of competencies concerns holders of a bachelor in "Mechanical Engineering". The generic competencies were evolved working in collaboration with four other subject-area groups (Civil Engineering, Medicine, Agriculture, and Teacher Education). Eighteen generic competences were agreed upon to represent characteristics desired in a holder of a first degree (Bachelor) in any subject area. Nineteen ME-specific competencies were developed through deliberations among representatives the 11 representatives of the participating universities working in the ME subject-group. Table 2 list both the generic and ME subject-specific competencies.

Table 2

List of generic and ME-specific competencies

\begin{tabular}{|l|l|}
\hline \multicolumn{1}{|c|}{ Generic Competencies } & \multicolumn{1}{|c|}{ ME Subject Specific Competencies } \\
\hline $\begin{array}{l}\text { 1. Ability for conceptual thinking, } \\
\text { analysis and synthesis }\end{array}$ & $\begin{array}{l}\text { 1. Ability to apply knowledge of } \\
\text { the basic and applied sciences of } \\
\text { mechanical engineering }\end{array}$ \\
\hline $\begin{array}{l}\text { 2. Professionalism, ethical values and } \\
\text { commitment to UBUNTU (respect for } \\
\text { the well being and dignity of fellow } \\
\text { human beings) }\end{array}$ & $\begin{array}{l}\text { 2. Ability to identify, evaluate and } \\
\text { implement the most appropriate } \\
\text { technologies for the context in hand }\end{array}$ \\
\hline
\end{tabular}


Table 2

List of generic and ME-specific competencies (continued)

\begin{tabular}{|c|c|}
\hline Generic Competencies & ME Subject Specific Competencies \\
\hline $\begin{array}{l}\text { 3. Capacity for critical evaluation and } \\
\text { self awareness }\end{array}$ & $\begin{array}{l}\text { 3. Capacity to create, innovate } \\
\text { and contribute to technological } \\
\text { development }\end{array}$ \\
\hline $\begin{array}{l}\text { 4. Ability to translate knowledge into } \\
\text { practice }\end{array}$ & $\begin{array}{l}\text { 4. Capacity to conceive, analyze, } \\
\text { design and manufacture mechanical } \\
\text { products and systems }\end{array}$ \\
\hline $\begin{array}{l}\text { 5. Objective decision making and } \\
\text { practical cost effective problem solving }\end{array}$ & $\begin{array}{l}\text { 5. Skills in planning and executing } \\
\text { mechanical engineering projects }\end{array}$ \\
\hline $\begin{array}{l}\text { 6. Capacity to use innovative and } \\
\text { appropriate technologies }\end{array}$ & $\begin{array}{l}\text { 6. Capacity to supervise, inspect and } \\
\text { monitor mechanical engineering } \\
\text { systems }\end{array}$ \\
\hline $\begin{array}{l}\text { 7. Ability to communicate effectively } \\
\text { in official/ national and local } \\
\text { language }\end{array}$ & $\begin{array}{l}\text { 7. Capacity to operate, maintain and } \\
\text { rehabilitate mechanical engineering } \\
\text { systems }\end{array}$ \\
\hline $\begin{array}{l}\text { 8. Ability to learn to learn and } \\
\text { capacity for lifelong learning }\end{array}$ & $\begin{array}{l}\text { 8. Skills in evaluating the } \\
\text { environmental and socio-economic } \\
\text { impact of mechanical projects }\end{array}$ \\
\hline $\begin{array}{l}\text { 9. Flexibility, adaptability and ability } \\
\text { to anticipate and respond to new } \\
\text { situations }\end{array}$ & $\begin{array}{l}\text { 9. Capacity to model and simulate } \\
\text { mechanical engineering systems and } \\
\text { processes }\end{array}$ \\
\hline $\begin{array}{l}\text { 10. Ability for creative and innovative } \\
\text { thinking }\end{array}$ & $\begin{array}{l}\text { 10. Skills in selecting, mobilizing and } \\
\text { administering material resources, } \\
\text { tools and equipment cost-effectively }\end{array}$ \\
\hline $\begin{array}{l}\text { 11. Leadership, management and } \\
\text { team work skills }\end{array}$ & $\begin{array}{l}\text { 11. Capacity to integrate legal, } \\
\text { economic and financial aspects } \\
\text { in decision-making in mechanical } \\
\text { engineering projects }\end{array}$ \\
\hline $\begin{array}{l}\text { 12. Communication and interpersonal } \\
\text { skills }\end{array}$ & $\begin{array}{l}\text { 12. Capacity for spatial abstraction, } \\
\text { graphic representation and } \\
\text { engineering drawings }\end{array}$ \\
\hline $\begin{array}{l}\text { 13. Environmental and economic } \\
\text { consciousness }\end{array}$ & $\begin{array}{l}\text { 13. Providing mechanical engineering } \\
\text { solutions to societal problems for } \\
\text { sustainable development }\end{array}$ \\
\hline $\begin{array}{l}\text { 14. Ability to work in an intra and } \\
\text { intercultural and/or international } \\
\text { context }\end{array}$ & $\begin{array}{l}\text { 14. Skills in safety and risk } \\
\text { management in mechanical } \\
\text { engineering systems }\end{array}$ \\
\hline
\end{tabular}


Table 2

List of generic and ME-specific competencies (continued)

\begin{tabular}{|l|l|}
\hline \multicolumn{1}{|c|}{ Generic Competencies } & \multicolumn{1}{|c|}{ ME Subject Specific Competencies } \\
\hline 15. Ability to work independently & $\begin{array}{l}\text { 15. Skills in using information } \\
\text { technologies, software and tools for } \\
\text { mechanical engineering }\end{array}$ \\
\hline $\begin{array}{l}\text { 16. Ability to evaluate, review and } \\
\text { enhance quality }\end{array}$ & $\begin{array}{l}\text { 16. Capacity to interact with } \\
\text { multidisciplinary groups towards } \\
\text { developing integrated solutions }\end{array}$ \\
\hline $\begin{array}{l}\text { 17. Self confidence, entrepreneurial } \\
\text { spirit and skills }\end{array}$ & $\begin{array}{l}\text { 17. Skills in employing quality control } \\
\text { techniques in managing materials, } \\
\text { products, resources and services }\end{array}$ \\
\hline $\begin{array}{l}\text { 18. Commitment to preserve and to } \\
\text { add value to the African identity and } \\
\text { cultural heritage }\end{array}$ & $\begin{array}{l}\text { 18. Capacity to conduct life cycle } \\
\text { assessment for products and systems }\end{array}$ \\
\hline & $\begin{array}{l}\text { 19. Capacity to employ mechanical } \\
\text { engineering skills to transform local } \\
\text { natural resources into products or } \\
\text { services through value addition }\end{array}$ \\
\hline
\end{tabular}

\section{Results of consultation process}

A total of 4323 stakeholder respondents returned the generic competencies questionnaire, while a total of 3812 respondents provided answers to the 5 sets of questions in the "subject specific" competencies questionnaire. About $13 \%$ of the responses came from the ME stakeholders. Analyses of stakeholder responses were conducted using the following procedure:

i. Competencies are ordered in a descending order of importance as seen by the stakeholders.

ii. Levels of achievement corresponding to (i) are recorded,

iii. The gap between (i) and (ii) for each competence is determined.

iv. Ranking of each of the 18 generic competencies is then recorded

v. The top-7, the bottom-7 and the middle 4 generic competencies, as well as the top-7, bottom-7 and the middle 5 of the 19 ME subjectspecific competencies are established. 
The final ranking of each competence was established after processing stakeholder responses in which they individually ranked competencies in a descending order of importance. The competence ranked "most important" by the highest number of stakeholders became competence number one in terms of ranking.

\section{Analysis of consultation results - generic competencies}

Thorough analysis of data from the consultation process yielded the following observations in regard to generic competencies (refer Table 2):

i. Generally, the level of achievement of a generic competence is scored lower than its level of importance, with the highest gaps occurring where the competencies in question have to do with use of innovative technologies, ability for creative and innovative thinking. It becomes obvious that innovative thinking is an inherent ideal of the ME discipline.

ii. Conceptual thinking and translating knowledge into practice are at the top of the list of competences in terms of importance and ranking, while competencies relating to the environment, quality, intra-cultural issues, and the African identity are at the bottom.

iii. Students and graduates rank creation of technology much higher than its mere use, whereas for employers the reverse is true, a known feature of African industry with a preference by firms (i.e. employers) for importing, and not developing, technology.

iv. Students and graduates of ME background rank leadership and teamwork much higher than do ME academics and employers of mechanical engineers.

v. For ME graduates the largest gap between importance and achievement is observed for entrepreneurial talent and selfconfidence. These represent examples of competencies that need rectification, improvement, and reinforcement in current curricula.

vi. Effective communication in local national languages is ranked low. This feature reflects the fact that local/national languages are not typically employed in technical communications and reporting in the Mechanical Engineering profession. 


\section{Analysis of consultation results - ME-specific competencies}

Analysis of data from the consultation process for ME specific competencies, resulted in the following observations (refer Table 2):

i. As in the case of generic competences, levels of achievement are scored lower than levels of importance by all stakeholders. Risk management, efficient use of natural resources, life cycle assessment, and working in multi-disciplinary teams turn out as competences with the largest gaps between levels of importance and achievement.

ii. The most highly ranked competencies are associated with abilities to apply of knowledge of the basic and applied mechanical engineering sciences, capacity to conceive, design, analyse and manufacture products and systems. Further, provision of ME solutions in a sustainable way is ranked high. Projects that would create or improve technology.

iii. Creation of technology and its innovation is ranked high by all stakeholders, except employers, probably reflecting their desire to use technology and not to "waste time" on Research and Development

iv. Competencies related to safety and risk assessment, quality control, and life cycle assessment are ranked very low by almost all stakeholders. This mirrors the low level of technological development in the continent.

The procedure followed in establishing the final ranking of each ME specific competence was similar to that used for the generic competences.

\section{Profile development}

In summarizing the key professional tasks of a mechanical engineer forming the basis for a corresponding meta-profile, the findings from the stakeholder consultation phase have been extensively utilized. It was thus agreed that the core elements of a ME programme can be represented as "Design, Manufacture and Operate Mechanical Systems". "Design" aims to realise new or modified artefacts or systems, with the intention of creating value in accordance with predefined requirements and desires. ${ }^{11}$

11 A.W.M. Meijers et. al., "Criteria for Academic Bachelors and Masters curricula," Technical University of Eindhoven, 90-386-2217-1, Eindhoven, 2005. 
"Manufacturing" involves translating design (digital or otherwise) into physical reality while "Operation" inherently implies safe and efficient use or application of the system.

\section{Constituent profiles and clusters}

The process for developing the Meta-Profile started with the formulation first of a professional profile with key occupational tasks. This was followed by the creation of a graduate profile, with (selected) core competencies that relate directly to the professional profile and subsequently to the curriculum profile where the final attainment levels of the graduate are defined in competence standards for both generic and specific competencies. This approach is in line with the development of a competency-based curriculum. ${ }^{2}$ For greater clarity, competency is understood to be the capability to choose and use (apply) an integrated combination of knowledge, skills and attitudes with the intention of executing a task up to standard in a certain context, with personal characteristics such as motivation, self-confidence, will power being part of that context. ${ }^{13}$

\section{Profile clusters}

Based on a ranking of the generic and ME specific competencies arising out of the consultation results, clustering was done in terms of cognitive attributes - the drivers and the driven. Drivers are grouped under different categories such as knowledge, skills and attitudes. The driving and the driven elements are conceptualized in terms of gears, as illustrated in Figure 1. The system is represented by a central core (Design, manufacture, and operate ME systems), surrounded by 6 competence sub-groups (3 knowledge competencies and 3 skill competencies, termed here as planets). These subgroups are in turn surrounded by 3 outer sub-groups (attitude competencies). These are then regrouped to form profile (core, knowledge, skills and attitudes) clusters.

${ }^{12}$ Kouwenhoven, W., "Competence-based Curriculum Development in Higher Education: a Globalised Concept," in Technology Education and Development, ed. by Aleksandar Lazinica and Carlos (InTech, 2009).

${ }^{13}$ Michael Cantrell et al., eds.,"Competence-based curriculum development in higher education: some African experiences," in Access \& Expansion: Challenges for Higher Education Improvement in Developing Countries (Amsterdam, The Netherlands: University Press, 2010), 221, http://hdl.handle.net/1871/15816, 2010. 


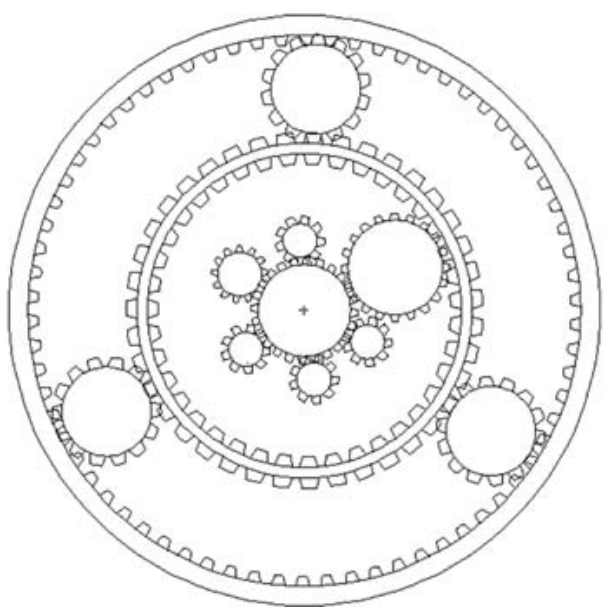

Figure 1

Mechanical Engineering Meta-profile: a pictorial version

(One Centre gear: represents ME core competencies

Six Intermediate gears: represents skill competencies

Three outer gears: represents attitude competencies)

\subsection{Core and knowledge clusters}

After reviewing ME degree profiles and learning outcomes from the participating universities, a consensus emerged with regard to the core elements of a ME curriculum. These together constitute the key elements of the enabling preparation needed by mechanical engineering trainees to function effectively according to the Conceive, Design, Implement, and Operate $(\mathrm{CDIO})^{14}$ framework paradigm. These core elements are shown in Figure 2. Each of the competency clusters including the ME core elements is constituted by both specific and generic competencies, with the exception of innovation and creativity and entrepreneurial skills. Broadly, this suggests that the competencies aid and reinforce each other. Ability to be creative and do innovative thinking and the capacity to contribute to technological development are adjoined with the core competency cluster. This is especially important in the African context, which is known to be characterized by low

14 “Worldwide CDIO Initiative," www.cdio.org. 
levels of technological development, thus emphasizing the need not only for cost effective utilization of scarce resources but also for acquiring a competitive edge in the global context. A range of ME specific competencies attempt to address this challenge, recognising also that the ability to transform local national resources into products or services through value addition is central. Even under the ME Sciences cluster, it becomes clear that the ability to translate knowledge into practice requires far more than mere acquisition of knowledge. More important is what can be done or realized with that knowledge. The Quality cluster completes the knowledge group of competency clusters, where apart from quality related aspects, safety and risk assessment are appropriately highlighted.

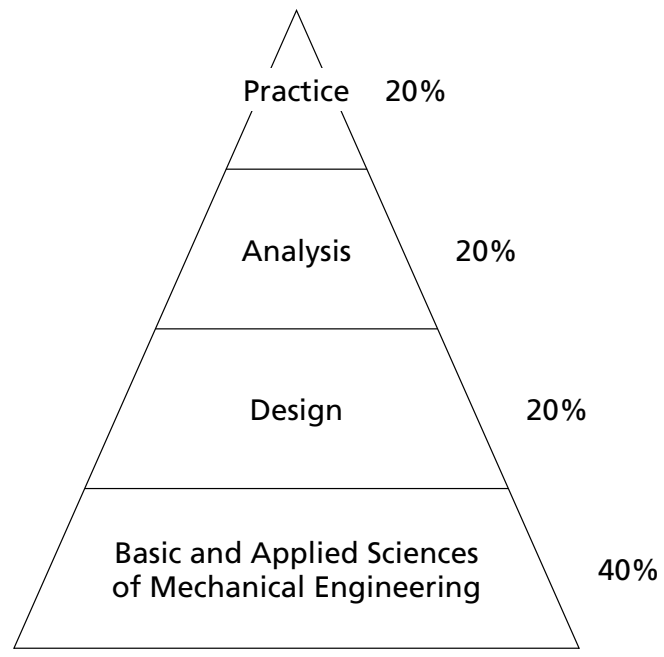

Figure 2

Core Elements of a First Degree in Mechanical Engineering

\subsection{Skills cluster}

A plethora of skills needed by ME graduates encompassing resource management (both material and human), practical problem solving, leadership, team work, cost effective decision making, planning, supervision, monitoring and execution of ME projects, is grouped under a Managerial and Behavioural cluster. Communication (technical drafting/drawing as well as verbal) is given due importance under a communication and interpersonal 
skills cluster with the ability to use information and communication technologies (ICTs) included.

\subsection{Attitudes cluster}

Positive attitudes relating to serving the wider society and influencing sustainable development form the central theme under this cluster grouping. The entrepreneurial skills cluster, having ability for creative and innovative thinking as the common thread, signifies the need for entrepreneurial spirit, self-confidence and the capacity to use innovative and appropriate technologies to suit the context in hand. The community engagement cluster is an embodiment of the need for leveraging ME solutions to societal and local community development problems. The need for a sustainability outlook is encapsulated by the abilities for socio-economic and environmental impact assessment of ME projects as well as life cycle assessment of products and systems as a separate competency cluster under this grouping. The integration of legal and financial aspects is again placed here due to its relevance. Strong emphasis on sustainability is especially important in a curriculum profile in the present day context.

\subsection{The meta-profile}

Recalling the assemblage of driving and driven gears from Figure 1, the linkages and the relationships among different factors as well as the synergy between various competency clusters in delivering and realizing the ME core functions of design, manufacture and operation of mechanical systems, can be easily understood. The inter-meshing gear teeth show the common subset space between the two competency clusters and this is extended by the other gears in contact as well.

In constructing the ME meta-profile, the ME core is conceived as a hexagonal space representing the core specializations as well as the core professional tasks presented earlier, inter-connected and serviced by the 6 planets and the 3 outer spaces at the apexes of the outer triangle of Figure 3. The 6 planets represent ME Sciences, Innovation \& Creativity, Quality, Managerial and Behavioural skills, Communication and Interpersonal skills, Professionalism and Ethics while the outer spaces represent Community Engagement, Entrepreneurial skills and Sustainability. The resulting metaprofile is depicted in Figure 3. 


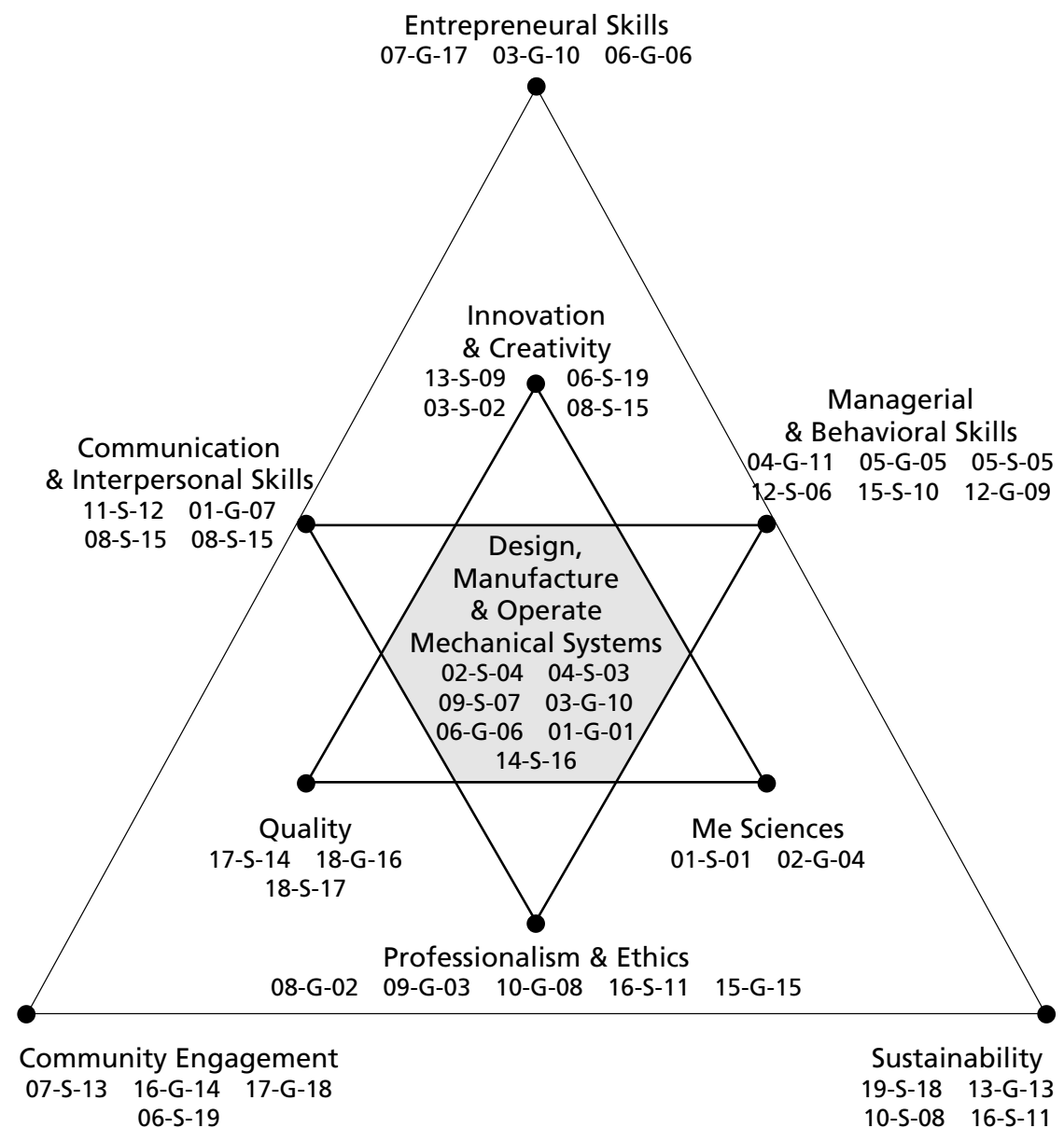

Figure 3

Graphical Representation of ME Degree Meta-Profile (a competence coded 06-S-19 is interpreted as: the ME specific competence whose original order is (19) and final ranking (06))

In the meta-profile, the groups of competencies associated with the core, the 6 planets and 3 outer spaces in Figure 3 are written according to the following code: Final Rank-Type (G or S)-Original Order. Thus, a competence coded as $08-\mathrm{G}-02$ is interpreted as: the generic competence whose original order is (02) and final ranking is (08). From the original list, this competence is readily identified as: Professionalism, Ethical Values and 
Commitment to UBUNTU (respect for the well-being and dignity of fellow human beings). Table 3 lists the coding for the other competency groupings.

\section{Table 3}

Construction of Mechanical Engineering Meta-Profile: Conceptual Basis

(A competence coded 08-G-02 is interpreted as: the generic competence whose original order is (02) and final ranking is (08))

\begin{tabular}{|c|c|c|c|c|c|c|c|}
\hline & Core & & Desigr & $\begin{array}{r}\text { Manufact, } \\
\text { Mechani }\end{array}$ & $\begin{array}{l}\text { and Oper } \\
\text { I Systems }\end{array}$ & tion of & \\
\hline Core- $A$ & ffiliated Competencies & $02-S-04$ & $04-5-03$ & $09-5-07$ & 03-G-10 & 06-G-06 & $\begin{array}{l}01-G-01 \\
14-S-16\end{array}$ \\
\hline Associate & $d$ Planets & & & & & & \\
\hline Planet-1 & $\begin{array}{l}\text { Mechanical } \\
\text { Engineering Sciences }\end{array}$ & 01-S-01 & $02-G-04$ & & & & \\
\hline Planet-2 & $\begin{array}{l}\text { Innovation and } \\
\text { Creativity }\end{array}$ & 13-S-09 & 03-S-02 & 06-S-19 & 08-S-15 & & \\
\hline Planet-3 & $\begin{array}{l}\text { Managerial and } \\
\text { Behavioural Skills }\end{array}$ & 04-G-11 & 05-G-05 & 05-S-05 & $12-S-06$ & $15-S-10$ & $12-G-09$ \\
\hline Planet-4 & Quality & $17-S-14$ & $18-G-16$ & $18-S-17$ & & & \\
\hline Planet-5 & $\begin{array}{l}\text { Communication and } \\
\text { Interpersonal Skills }\end{array}$ & $11-\mathrm{S}-12$ & $14-G-07$ & $11-G-12$ & $08-S-15$ & & \\
\hline Planet-6 & $\begin{array}{l}\text { Professionalism and } \\
\text { Ethics }\end{array}$ & $08-G-02$ & 09-G03 & $10-G-08$ & $16-S-11$ & $15-G-15$ & \\
\hline Outer $S p$ & & & & & & & \\
\hline Space-1 & Entrepreneurial Skills & $07-G-17$ & 03-G-10 & $06-G-06$ & & & \\
\hline Space-2 & $\begin{array}{l}\text { Community } \\
\text { Engagement }\end{array}$ & $07-S-13$ & $16-G-14$ & $17-G-18$ & 06-S-19 & & \\
\hline Space-3 & Sustainability & 19-S-18 & $13-G-13$ & $10-S-08$ & $16-S-11$ & & \\
\hline
\end{tabular}

\section{Discussion}

The Tuning project gives Africa an instrument which can improve teaching and learning methods with a view to enhancing the curricula of $\mathrm{HE}$ institutions. Analysis of consultation data with stakeholders regarding generic and $\mathrm{ME}$ competencies yielded a number of important general observations. Levels of importance attached to competencies are much higher than extents of achievement of those competencies as seen by stakeholders. Having developed and defined generic and specific competences 
and the detailed meta-profile for ME, a comparison of the developed metaprofile is then made with existing degree profiles. In general the following observations set forth:

i. There exists a remarkable coincidence between the developed metaprofile and existing degree profiles especially in the ME core area of designing, manufacturing and operations of ME systems.

ii. However, in other areas there is poor correlation between the two, with existing degree profiles lacking in emphasis in the areas of innovation and creativity, managerial and behavioural skills and quality.

iii. Further, the existing degree profiles portray a serious lack of emphasis in the areas of professional ethics, community engagement, environmental, social and economic impact assessment as well as product life cycle assessment.

iv. Other areas of sharp differences between the two profiles include commitment to the African identity and provision of ME solutions towards sustainable development.

v. Whereas some established degree programmes incorporate aspects of legal and financial issues, in others they are totally absent.

vi. It is agreed that the developed profile is better than the existing profiles, in that the former not only addresses current societal expectations upon a ME graduate but also accommodates future expectations. Hence, there is a need to review and harmonize existing profiles with the developed one.

vii. It is imperative that the developed meta-profile be validated by other key stakeholders.

\section{Concluding remarks and recommendations}

In summary, 18 generic competences and 19 ME-specific competencies have been developed, analysed and synergised, with input from stakeholders, to form a meta-profile that will inform the basis for the next phase of the project, which is actual curriculum development.

As noted earlier, the aim is to collaboratively contribute to make ME training more responsive to Africa's developmental needs. These needs include building the capability to exploit opportunities for increased intraAfrican trade, expanding transport networks and shared infrastructure, technology transfer, adaptation and assimilation as well as facing the 
challenges of engineering globalisation. These have brought to the fore the need for harmonisation of engineering programmes across Africa, and the development of curricula that address the above technological needs. All these will require cooperation amongst engineers from different African countries such that curriculum harmonisation will enhance intra-African engineering human resource mobility at various levels namely, high-level research in areas of specialization which support judicious use of scarce and expensive resources, postgraduate programmes in specialist areas, and joint engineering programmes based on intra-African meta-profiles. Thus the harmonization of mechanical engineering education in Africa, through the developed meta-profile, could lay the foundation for addressing those needs in the future.

The following future engagements are recommended to be pursued:

- Deepening the process by defining detailed learning objectives and outcomes.

- Carrying out gap analysis between existing curricula and the developed meta-profile.

- Extending the process to cover: Civil, Electrical and Chemical engineering disciplines.

- Developing generic competencies for all engineering disciplines.

- Subjecting future work to a validation process, disseminating findings to a wider population and addressing implementation challenges.

\section{Bibliography}

Alarcon, Francisco, Pablo Beneitone, Roberto de Armas, Sergio Kieling, Leticia Sune, and Diana Veneros. "Student Workload and Degree Profiles: the experience of CLAR credit in Latin America." Tuning Journal for Higher Education, no. 1 (2013): 165-186.

Galal Abdel-Hamid Abdellah et al. "Recent developments in Egyptian engineering education through competitive projects." 2008. Paper presented at the Third African Regional Conference on Engineering Education (ARCEE), Pretoria, South Africa, courtesy the African Engineering Education Association (AEEA), September 26-27, 2006.

Hahn, Karola, and Damtew Teferra. "Tuning as instrument of systematic Higher Education reform and quality enhancement: the African experience." Tuning Journal for Higher Education, no. 1 (2013): 127-163.

Jackson, H., K. Tarhini, A. Zapalska, and S. Zelmanowitz. "Strategies to Infuse Global Perspectives and Industrial Collaboration in Engineering Education." 
Paper presented at the $40^{\text {th }}$ ASEE/IEEE Frontiers in Education Conference, Washington, DC, October, 2010.

Kouwenhoven, W. "Competence-based Curriculum Development in Higher Education: a Globalised Concept." In Technology Education and Development, edited by Aleksandar Lazinica and Carlos Calafate. InTech, 2009.

Cantrell, M., M. Kool, and W. Kouwenhoven, eds. "Competence-based curriculum development in higher education: some African experiences." In Access \& Expansion: Challenges for Higher Education Improvement in Developing Countries. Amsterdam, The Netherlands: University Press, 2010. http://hdl. handle.net/1871/15816, 2010.

Kumar, V., Karl R. Haapala, Julio L. Rivera, Margot J. Hutchins, William J. Endres, John K. Gershenson, Donna J. Michalek, and John W. Sutherland. "Infusing sustainability principles into manufacturing/mechanical engineering curricula." Journal of Manufacturing Systems 24, no. 3 (2005): 215-225.

Markes, I. "A review of literature on employability skills needs in engineering." European Journal of Engineering Education 31, no. 6 (2006): 637-650.

Martín P., Ignacio de los R., and Dante G. "Higher Education in Industrial Engineering in Peru: Towards a New Model Based on Skills." Procedia - Social and Behavioral Sciences 46, no. 2 (2012): 1570-1580. Paper presented at the 4th World Conference on Educational Sciences (WCES-2012), February 2-5, 2012 Barcelona, Spain.

Meijers, A.W.M. et al. "Criteria for Academic Bachelors and Masters curricula." Technical University of Eindhoven, 90-386-2217-1, Eindhoven, 2005.

- "The ABET "Professional Skills" - Can They Be Taught? Can They Be Assessed?" Journal of Engineering Education 94, no. 1 (2005): 41-56.

Strobel, J., Wang, J., Weber, N.R., and Dyehouse, M. "The role of authencity in design-based learning environments: The case of engineering education." Computers \& Education 64 (May 2013): 143-152.

"Worldwide CDIO Initiative." www.cdio.org. 